\title{
ANALISIS PENGARUH KEPERCAYAAN DAN KEAMANAN TERHADAP KEPUTUSAN PEMBELIAN BARANG SECARA ONLINE
}

\author{
Jefryansyah ${ }^{1)}$ \\ jefryansyah009@gmail.com \\ Sekolah Tinggi Ilmu Ekonomi (STIE) Bima \\ Muhajirin') \\ jirin.stiebima@gmail.com \\ Sekolah Tinggi Ilmu Ekonomi (STIE) Bima
}

\begin{abstract}
Abstrak
Seiring dengan kemajuan teknologi informasi, diikuti oleh semakin mudah dan murahnya akses dan paket internet, maka jumlah pengguna internet di Indonesia mengalami peningkatan yang sangat pesat. Perkembangan teknologi informasi ini membuat perubahan perilaku bertransaksi dikalangan masyarakat, yang dari dulunya offline menjadi bertransaksi secara online. Tujuan yang ingin di capai adalah untuk meningkatkan kepercayaan serta keamanan yang di berikan oleh situs jualan online agar minat beli dari konsumen itu sendri meningkat. Data yang digunakan adalah data primer. Sampel penelitian berjumlah 130 responden mahasiswa stie bima yang pernah berbelanja pada toko online. Alat analisis dalam penelitian ini menggunakan regresi linier berganda. Hasil penelitian ini menujukan bahwa kepercayaan berpengaruh positif dan signifikan terhadap keputusan pembelian barang secara online, keamanan berpengaruh positif dan signifikan terhadap keputusan pembelian barang secara online dan terdapat pengaruh positif dan signifikan kepercayaan dan keamanan terhadap keputusan pembelian barang secara online. Sehingga semakin tinggi kepercayaan konsumen, serta semakin tinggi tingkat keamanan yang di berikan, maka semakin tinggi pula keputusan pembelian barang secara online.
\end{abstract}

Kata Kunci : kepercayaan, keamanan, keputusan pembelian

\section{Pendahuluan}

Seiring dengan kemajuan teknologi informasi, diikuti oleh semakin mudah dan murahnya akses dan paket internet, maka jumlah pengguna internet di Indonesia mengalami peningkatan yang pesat. Perkembangan yang sangat pesat ini membuat perubahan perilaku bertransaksi di kalangan masyarakat, yang dari dulunya offline menjadi bertransaksi secara online. Dengan berbekal akses internet yang bisa digunakan 24 jam, kita sangat dimudahkan untuk mencari barang-barang yang ingin dibeli atau menawarkan barang-barang yang ingin kita jual. Maka tidak heran jika saat ini belanja online pun menjadi salah satu jalan bagi konsumen yang ingin berbelanja atau penjual yang ingin menawarkan produk-produknya.

Dilihat dari data statistik saat ini menunjukkan bahwa pengguna internet di Indonesia terus meningkat setiap tahunnya, menurut survey yang diselenggarakan Asosiasi Penyelenggaraan Jasa Internet (APJII) mengungkapkan bahwa jumlah pengguna internet di Indonesia pada tahun 2017 yaitu 143,26 juta jiwa dari total populasi Indonesia. Sementara pertumbuhan pengguna internet di Indonesia bertambah lagi menjadi 10,12 persen pada 2018 dibandingkan tahun sebelumnya. Secara total, pengguna internet mencapai 171,17 juta pengguna dari populasi 264,16 juta jiwa. Dengan rincian 5,2\% saja penggunaan internet untuk di wilayah Bali dan Nusatenggara.

Kepercayaan merupakan sebuah keyakinan dari salah satu pihak mengenai maksud dan perilaku yang ditujukan kepada pihak yang lainnya, dengan demikian kepercayaan konsumen didefinisikan sebagai suatu harapan konsumen bahwa penyedia 
jasa bisa dipercaya atau diandalkan dalam memenuhi janjinya (Siagian dan Cahyono, 2014).

Park dan Kim (2006) dalam Sukma (2012) mendefinisikan keamanan (security) sebagai suatu kemampuan dari toko online dalam melakukan. pengontrolan dan penjagaan keamanan atas transaksi data. Keamanan menjadi bagian penting dalam proses pembentukan kepercayaan dengan mengurangi perhatian konsumen tentang penyalahgunaan data pribadi dan transaksi data yang mudah rusak. Keamanan merupakan faktor yang sangat penting untuk meningkatkan kepercayaan konsumen terhadap niat bertransaksi dan keputusan pembelian secara online.

Sekarang ini sosial media telah mengalami berbagai perkembangan dalam hal fungsi, di mana sosial media yang sering dikunjungi bukan hanya digunakan untuk berinteraksi atau berkirim pesan saja, akan tetapi media sosial pada jaman ini dimanfaatkan lebih maju dan bijak untuk dapat melakukan bisnis jual beli. Mudahnya memasarkan produk melalui sosial media, serta banyaknya manfaat yang diberikan seperti, jangkauan pasar yang lebih luas, berbelanja dengan nyaman, dapat melakukan perbandingan harga dan perbandingan produk pada beberapa toko online hanya dalam hitungan detik dan hal ini sangat memungkinkan komunikasi yang lebih dekat dan intens dengan konsumen,serta membantu pelaku bisnis untuk dapat meningkatkan penjualan mereka.Kebutuhan konsumen perlu diidentifikasi secara jelas, sebagai bagian dari pengembangan produk.

Di kota Bima sendiri perkembangan penjualan yang memanfaatkan situs jejaring sosial/e-commerce terhitung sangat banyak sekali, tidak jarang kita melihat pada situs jejaring sosial di jadikan media promosi barang dagangan mereka, yang berupa barangkebutuhan hidup sosial konsumen. Karena semakin banyak orang yang berbelanja online maka semakin banyak orang yang menyalahgunakan media jual online yang dapat merugikan orang lain.

Berbagai permasalahan yang sering dijumpai oleh konsumen dalam berbelanja dengan menggunakan situs jualan online antara lain adalah tingkat kepercayaan konsumen yang kurang serta keamanan dalam berbelanja online yang di rasa juga kurang, kepercayaan terhadap tindakan penipuan atas barang yang akan dibeli tidak sesuai seperti pada keterangan dari penjualan atau misalnya jika kosumen sudah melakukan transfer sejumhlah uang untuk membeli barang tersebut akan tetapi barang tersebut tidak di kirimkan, serta keamanaan akan barang sampai dengan selamat atau tidaknya. Ini semua menjadi faktor yang masih di permasalahkan oleh konsumen yang ingin berbelanja barang secara online.

Dalam masyarakat saat ini, khususnya di Kota Bima diera yang modern ini, faktor kepercayaan dan keamanan konsumen dalam berbelanja menjadi hal yang harus di perhatikan, dimana akan mempengaruhi minat dan keputusan konsumen dalam membeli produk. Resiko-resiko yang mungkin timbul dalam pembelian secara online tentu saja akan mempengaruhi tingkat kepercayaan konsumen pada bisnis online. Semakin tinggi tingkat risiko yang mungkin terjadi akan menurunkan kepercayaan konsumen dalam pembelian secara online. Tujuan penelitian yang ingin di capai adalah meningkatnya kepercayaan serta keamanan dalam pembelian barang secara online yang di lakukan oleh konsumen. 


\section{Tinjauan Teori}

Menurut Gunawan (2013), kepercayaan didefinisikan sebagai bentuk sikap yang menunjukkan perasaan suka dan tetap bertahan untuk menggunakan suatu produk atau merek. Selanjutnya Sumarwan (2011) menyatakan bahwa kepercayaan konsumen adalah pengetahuan konsumen mengenai suatu objek, atributnya, dan manfaatnya. Berdasarkan konsep tersebut, maka pengetahuan konsumen sangat terkait dengan pembahasan sikap karena pengetahuan konsumen adalah kepercayaan konsumen. Kepercayaan akan timbul dari benak konsumen apabila produk yang dibeli mampu memberikan manfaat atau nilai yang diinginkan konsumen pada suatu produk. Suatu kepercayaan umumnya adalah sebuah niat kepercayaan yang membawa pihak lain dapat dipercayai atau memberikan kesediaan suatu pihak untuk peka terhadap sebuah tindakan yang dilakukan oleh pihak lainnya (Kim et al, dalam Sukma, Abdurahman Adi, 2012). Ada banyak indikator yang dapat digunakan untuk mengukur tingkat kepercayaan konsumen. Indikator kepercayaan yang dikutip dari Kim et al (dalam Sukma, Abdurrahman, Adi, 2012) adalah sebagai berikut: 1) Jaminan Kepuasan, 2) Perhatian, 3) Keterus-terangan.

Park dan Kim (2006) dalam Sukma (2012) mendefinisikan keamanan (security) sebagai suatu kemampuan dari toko online dalam melakukan pengontrolan dan penjagaan keamanan atas transaksi data. Park dan Kim (2006) dalam Sukma, Abdurahman, Adi (2012), juga mengatakan bahwa jaminan keamanan menjadi bagian penting dalam proses pembentukan kepercayaan dengan mengurangi perhatian konsumen tentang penyalahgunaan data pribadi dan transaksi data yang mudah rusak. Variabel keamanan meliputi 5 indikator (Maulina Hardiyanti, 2012) yaitu: 1) Terjaminnya transaksi, 2) Kemudahan transaksi melalui COD (Cash On Delivery) ataupun transfer, 3) Bukti transaksi melalui nomor resi pengiriman, 4) Citra penjual online, dan 5) Kualitas produk.

Keputusan pembelian adalah suatu tindakan yang dilakukan konsumen untuk membeli suatu barang atau jasa yang diawali untuk pemenuhan kebutuhan dan diakhiri dengan melakukan seleksi atas alternative-alternative tentang barang atau jasa yang tersedia. Variabel keputusan pembelian diukur dengan menggunakan skala Likert. Indikator-indikator variable keputusan pembelian meliputi (Maulina Hardiyanti, 2012), : 1) Keyakinan dalam membeli, 2) Sesuai dengan keinginan, 3) Memiliki keinginan untuk membeli ulang, 4) Mempertimbangkan kualitas produk, dan 5) Merekomendasikan kepada orang lain.

Penelitian yang dilakukan oleh Florentinus Bigar Anung Anandita (2015) dengan judul Analisis Pengaruh Kepercayaan, Keamanan, Kualitas Pelayanan, Dan Persepsi Akan Resiko Terhadap Keputusan Pembelian Melalui Situs Jejaring Sosial menyatakan terdapat pengaruh yang signifikan kepercayaan terhadap keputusan pembelian melalui situs jejaring sosial (social networking websites). Sedangkan Andy Putra Mahkota (2014) megatakan bahwa Variabel kepercayaan memiliki pengaruh yang signifikan terhadap keputusan pembelian online sesuai dengan hasil penelitian. Semakin tinggi tingkat kepercayaan seseorang terhadap pihak Ride Inc dalam melakukan hubungan transaksi berdasarkan suatu keyakinan bahwa Ride Inc akan memenuhi kewajibannya dengan baik, maka responden akan memutuskan untuk membeli produk pada website Ride Inc. Hal ini menunjukkan bahwa kepercayaan dapat mempengaruhi keputusan pembelian online

$\mathrm{H} 1$ = Faktor kepercayaan (trust) berpengaruh signifikan terhadap keputusan pembelian barang secara online

Nahla Rahma Yunita (2019), melalui studi yang dilakukan pada Kasus Komunitas Buka Lapak Ponorogo, menemukan bahwa faktor keamanan memiliki hubungan yang positif dan signifikan dalam mempengaruhi keputusan pembelian secara online. Dan 
Ilham Tugiso(2016) menegemukakan pula berdasarkan hipotesa Variabel keamanan (X2) memiliki nilai $\mathrm{t}$ hitung sebesar $2.331>\mathrm{t}$ tabel 1.66600 dan tingkat signifikansi $\mathrm{t}$ hitung $0.002<\alpha=0.05$ (one taile) dan bertanda positif, dengan demikian dapat dikatakan bahwa kemanan berpengaruh positif dan signifikan terhadap keputusan pembelian dan loyalitas pelanggan terhadap minat beli ulang konsumen pada produk Online Shop "NUMIRA" Semarang

$\mathrm{H} 2$ = Faktor keamanan (security) berpengaruh signifikan terhadap keputusan pembelian barang secara online.

\section{Kerangka Konseptual}

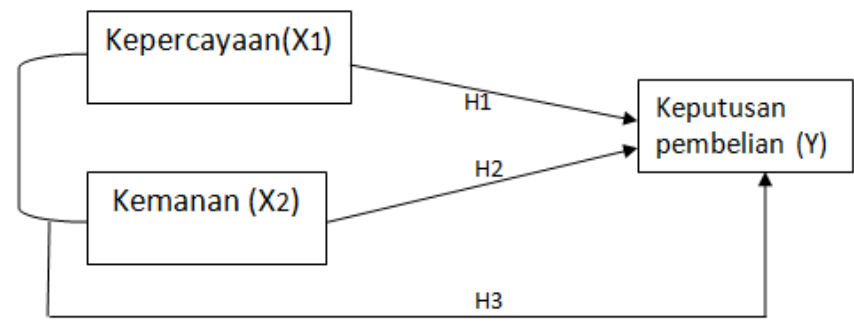

\section{Gambar Kerangka teoritis}

Berdasarkan konsep penelitian, maka hipotesis penelitian adalah sebagai berikut:

- H1 : Kepercayaan berpengaruh secara parsial terhadap keputusan pembelian baraang secara online

- H2: Keamanan berpengaruh secara parsial terhadap keputusan pembelian barang secar online

- H3: Kepercayaan dan Keamanan berpengaruh secara simultan terhadap keputusan pembelian barang secara online

\section{Metode Penelitian}

Lokasi penelitian dilakukan di Kota Bima. Penelitian dilakukan bulan Desember 2019 sampai Januari 2020. Jenis penelitian yang digunakan dalam penelitian ini adalah menggunakan penelitian asosiatif. Jenis data yang digunakan adalah data kuantitatif dengan tiga variable yaitu kepercayaan, keamanan dan keputusan pembelian. Sumber data menggunakan data primer dan dikumpulkan secara langsung dengan menggunakan kuisioner (angket). Populasi dalam penelitian ini adalah seluruh mahasiswa Sekolah Tinggi Ilmu Ekonomi Bima semester III dan V yang pernah melakukan jual beli barang secara online. Jumlah sampel yang representatif adalah tergantung jumlah indikator dikalikan 5 sampai 10 (Hair, et, al, 2010). Jumlah sampel = jumlah indikator (13) x 10 =130 Responden. Dengan mengacu ada perhitungan jumlah minimal sampel dan pertimbangan jumlah populasi yang ada, maka jumlah sampel yang dipilih adalah sebanyak 130 responden.

Nonprobability sampling adalah teknik pengambilan sampel yang tidak memberi peluang/kesempatan sama bagi setiap unsur atau anggota populasi untuk dipilih menjadi sampel (Sugiyono, 2016 : 89). Teknik nonprobability sampling yang digunakan penulis dalam penelitian ini yaitu dengan menggunakan teknik sampling purposive. Sampling purposive adalah teknik penentuan sampel dengan pertimbangan tertentu (Sugiyono, 2016 : 96). Alat analisis data dalam penelitian ini menggunakan regresi linear berganda dengan bantuan SPSS versi 20 for windows. 
5. Hasil dan Pembahasan

5.1. Uji Validitas

\begin{tabular}{|l|l|l|l|l|}
\hline $\begin{array}{c}|c| \\
\text { r. Hitung } \\
\text { Variabel } \mathrm{X} 1\end{array}$ & $\begin{array}{c}\text { r. Hitung } \\
\text { Variabel } \mathrm{X} 2\end{array}$ & $\begin{array}{c}\text { r. Hitumg } \\
\text { Variabel } \mathrm{Y}\end{array}$ & \multicolumn{1}{c|}{ r. Tabel } & \multicolumn{1}{c|}{ keterangan } \\
\hline$(\mathrm{X} 1.1) 0,718$ & $(\mathrm{X} 2.1) 0,751$ & $(\mathrm{Y} 1) 0,743$ & 0,300 & VALID \\
\hline$(\mathrm{X} 1.2) 0,833$ & $(\mathrm{X} 2.2) 0,490$ & $(\mathrm{Y} 2) 0,484$ & 0,300 & VALID \\
\hline $\mathrm{X} 1.3) 0,825$ & $(\mathrm{X} 2.3) 0,722$ & $(\mathrm{Y} 3) 0,577$ & 0,300 & VALID \\
\hline & $(\mathrm{X} 2.4) 0,820$ & $(\mathrm{Y} 4) 0,887$ & 0,300 & VALID \\
\hline & $(\mathrm{X} 2.5) 0,688$ & $(\mathrm{Y} 5) 0,846$ & 0,300 & VALID \\
\hline
\end{tabular}

Tabel. Validitas

Hasil pengujian validitas variabel Kepercayaan Dan Keamanan Terhadap Keputusan Pembelian dapat dikatakan valid pada Corrected item total correlation > 0,300 . Hasil pengujian validitas ini menunjukkan bahwa pernyataan kuesioner dalam penelitian ini valid.

\subsection{Uji Reliabilitas}

Taberedidilititas

\begin{tabular}{|c|c|c|}
\hline Variabel & Cronboch alpha & Keterangagan \\
\hline Kepercayaan (XI) & .697 & Reliabel \\
\hline Keamanan (X2) & .736 & Reliabel \\
\hline Keputusan pembelian (Y) & .768 & Reliabel \\
\hline
\end{tabular}

Tabel. Reliabilitas

Hasil Uji Relibialitas diatas menujukan bahwa item pertanyaan di tiga variabel memiliki nilai Cronbac halpha $>0,600$. Dengan demikian butir soal tersebut dinyatakan konsisten atau reliable/stabil, sehingga dapat dipergunakan untuk penelitian.

\subsection{Uji asumsi klasik}

Uji asumsi klasik adalah analisis yang dilakukan untuk menilai apakah di dalam sebuah model regresi linear Ordinary Least Square (OLS) terdapat masalah-masalah asumsi klasik.

\section{- Uji Normalitas}

Uji normalitas bertujuan untuk menguji apakah antara variabel dependen dan variabel independen memiliki distribusi data yang normal atau tidak. Pengujian normalitas data dalam penelitian ini menggunakan metode grafik PP-Plot. 


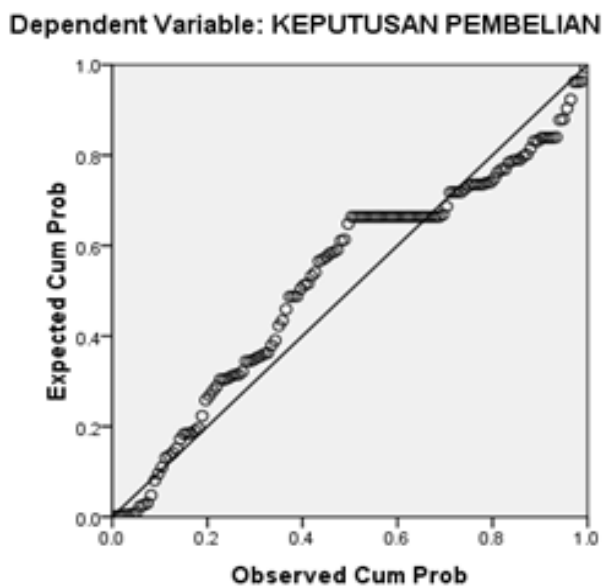

\section{Gambar Grafik PP-Plot Uji Asumsi Normalitas}

Dilihat dari gambar di atas menunjukan bahwa titik titik sejajar mengikti garis sumbunya, maka dapat di simpulkan bahwa data dalam penelitian ini berdistribusi secara normal.

\section{- $\quad$ Uji multikolinearitas}

Untuk mendeteksi ada tidaknya multikolinieritas dapat dilihat dari Variance Inflation Faktor (VIF). Apabila nilai VIF $>10$ maka menunjukkan adanya multikolinieritas. Apabila sebaliknya $\mathrm{VIF}<10$ maka tidak terjadi multikolinieritas. Pengujian asumsi multikolinier dapat dilihat pada tabel sebagai berikut:

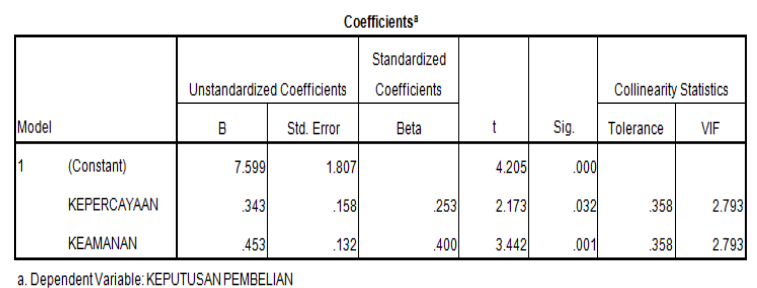

Tabel Multikolinearitas

Berdasrkan hasil perhitungan yang ada pada Tabel masing-masing variabel bebas menunjukkan nilai VIF, Untuk Pengujian Multikolinearitas pada penelitian ini dapat disimpulkan bahwa masing-masing sesudah menunjukkan nilai VIF yang tidak lebih dari 10, maka tidak terjadi multikolinieritas

\section{- $\quad$ Uji heterokedastisitas}

Pengujian asumsi heterokedastisitas dilakukan dengan melihat grafik plot. Indikasi terjadinya heterokedastisitas tampak pada pola tertentu yang dibentuk dalam plot. Apabila tidak terlihat adanya pola tertentu serta titik-titik penyebaran diatas dan dibawah sumbu $Y=0$, maka tidak diindikasikan adanya heterokedastisitas. 


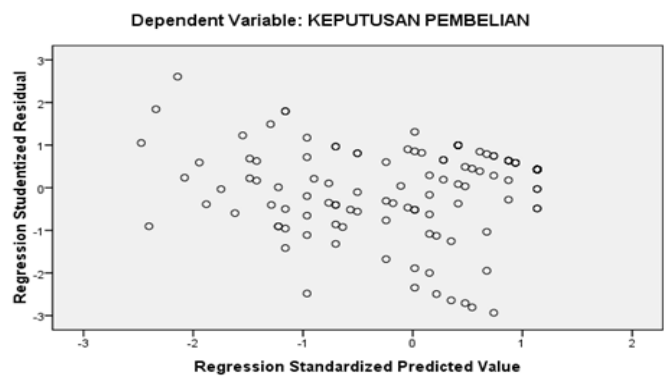

\section{Gambar Heteroskedastisitas}

Bentuk gambar diatas dapat dilihat bahwa penyebaran residual tidak teratur dan tidak membentuk pola. Hal tersebut dapat dilihat pada titik-titik plot yang menyebar, kesimpulan yang dapat diambil bahawa tidak terjadi residual

- $\quad$ Uji autokorelasi

Pengujian ada tidaknya autokorelasi pada regresi variabel dependen dilakukan dengan memeriksa statistik Durbin-Watson (DW).

\begin{tabular}{|c|c|c|c|c|c|}
\hline \multicolumn{6}{|c|}{ Model Summary ${ }^{\circ}$} \\
\hline Model & $R$ & R Square & $\begin{array}{l}\text { Adjusted R } \\
\text { Square }\end{array}$ & $\begin{array}{c}\text { Std. Error of the } \\
\text { Estimate }\end{array}$ & Durbin-Watson \\
\hline 1 & $.621^{\circ}$ & .386 & .376 & 2.206 & 1.463 \\
\hline
\end{tabular}

Tabel Autokorelasi

Nilai du dicaripadadistribusinilaitabledurbin Watson (dw) berdasarkan K (2) dan n (130) dengan signifikasi 5\%. Nilai Durbin Watson (d) sebesar 1,463< batas atas (du) yakni 1,744 dan < (4-du) 4-1,744=2,256, sebagaimana dasar keputusan dalam uji durbin Watson diatas maka dapa tditarik kesimpulan bahwa tidak terdapat masalah atau gejala autokorelasi

\subsection{Regresi linier berganda}

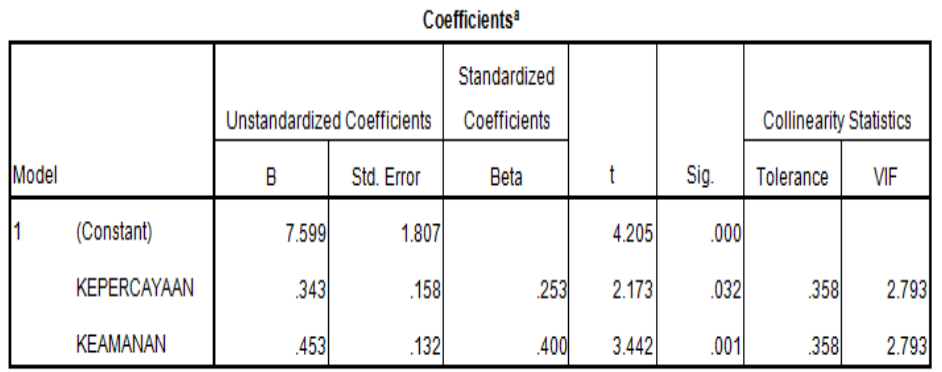

a. DependentVariable:KEPUTUSAN PEMBELIAN

Tabel. Regresi linier berganda 
'Nilai konstanta bernilai positif sebesar 7,599 hal ini menunjukkan apabila variabel kepercayaandankeamananbernilai nol, maka keputusan pembelian sebesar 7,599. Koefisien regresi variabel kepercayaan $\mathrm{X}_{1}$ bernilai positif sebesar 0,343 hal ini menunjukkan bahwa apabila kepercayaansemakin baik dengan asumsi variabel lain konstan, maka hal tersebut dapat meningkatkan keputusan pembelian sebesar 0.343 Koefisien regresi variabel keamananX2 bernilai positif sebesar 0.453 , hal ini menunjukkan apabila variabel keamanansemakin baik dengan asumsi variabel lain konstan, maka hal tersebut dapat meningkatkan keputusan pembelian sebesar 0.453

- $\quad$ Koefisien korelasi

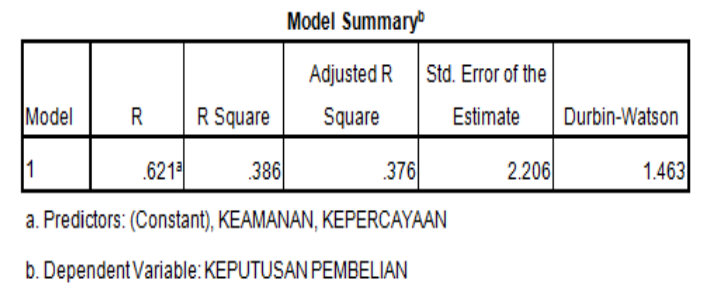

Tabel. Koefisien korelasi

Dari tabel di atas di peroleh nilai $\mathrm{R}$ sebesar 0,621 atau sebesar 62,1\%, sehingga dapat disimpulkan bahwa variabel kepercayaan dan keamanan hubungannya dengan keputusan pembelian sebesar $62,1 \%$

- $\quad$ Koefisien determinasi

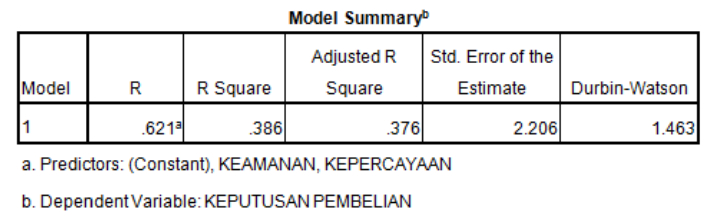

Tabel. Koefisien determinasi

Dari data di atas, dapat diketahui bahwa koefisien determinasi (R Square) yang diperoleh sebesar 0,386. Hal ini menunjukkan bahwa variabel kepercayaan dan keamanan hanya mempengaruhi sebesar $38,6 \%$ terhadap keputusan pembelian. Sedangkan sisanya $61,4 \%$ dipengaruhi oleh variabel lain yang tidak diteliti dalam penelitian ini.

\subsection{Uji Hipotesis (uji T dan F)}

Selanjutnya untuk mengetahui apakah hipotesis yang diajukan dalam penelitian ini diterima atau ditolak maka akan dilakukan pengujian hipotesis dengan menggunakan uji $\mathrm{t}$. Hasil pengujian hipotesis dijelaskan sebagai berikut:

Hipotesis 1 (uji T)

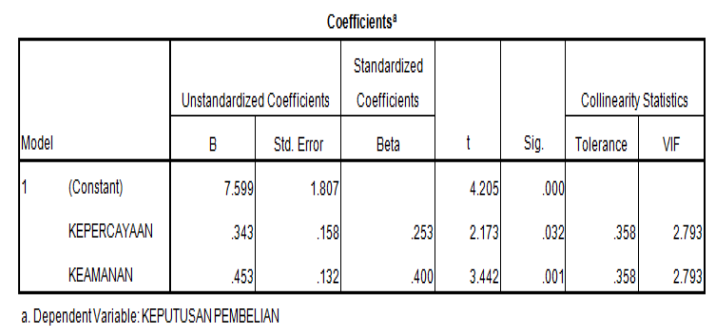


Dari gambar tabel di atas di simpulkan bahwa :

Variabel kepercayaan memiliki nilai thitung 2,173 > tabel 1,978, yang artinya bahwa variabel "kepercayaan berpengaruh terhadap keputusan pembelian barang secara online" apablia penjual yang menggunakan situs jualan online meningkatkan penjualan mereka maka faktor paling utama yang perlu di tingkatan adalah kepercayaan dari konsumen. Kepercayaan sangat penting bagi konsumen yang berbelaja apa lagi dengan menggunakan situs jualan online, karena jika konsumen merasa sudah di bohongi oleh penjual tingkat kepercayaannya menurun sehingga membuat daya beli konsumen yang menggunakan jasa jualan online pun ikut menurun, maka dari itu kepercayaan harus di utamakan oleh penjual dan menjadi faktor penting dalam bisnis usaha yang memanfaatkan jalur onine sebagai pusat dagangannya.

Hasil ini sejalan dengan apa yang di lakukan oleh peneliti sebelumnya yaitu Andy Putra Mahkota (2014) yang menyimpulkan bahwa kepercayaan berpengaruh terhadap keputusan pembelian secara online.

Variabel keamanan memiliki nilai thitung 3,442 > ttabel 1,978, yang artinya variabel "keamanan berpengaruh terhadap keputusan pembelian barang secara online" itu karena keamanan merupakan faktor yang paling penting dalam berbelanja online sebagai syarat dari konsumen agar mau berbelanja dengan menggunakan situs jualan online yang ada. Untuk meningkatan pejualan pula para penjual online haruslah memberikan rasa aman kepada para konsumen yang akan menggunakan jasa jualan online itu sendiri.

Penelitian ini di perkuat pula oleh hasil dari penelitian yang di lakukan oleh Nahla Rahma Yunita (2019) yang menyimpulakan hal yang sama yaitu keamanan memiliki pengaruh terhadap keputusan pembelian barang secara online.

Hipotesis 2 (uji F)

\begin{tabular}{|c|c|c|c|c|c|c|}
\hline \multicolumn{7}{|c|}{ ANOVA $^{D}$} \\
\hline \multicolumn{2}{|c|}{ Model } & Sum of Squares & df & Mean Square & $\mathrm{F}$ & Sig. \\
\hline \multirow[t]{3}{*}{1} & Regression & 387.931 & 2 & 193.966 & 39.875 & $.000^{\mathrm{a}}$ \\
\hline & Residual & 617.769 & 127 & 4.864 & & \\
\hline & Total & 1005.700 & 129 & & & \\
\hline
\end{tabular}

Dari hasil pengujian diperoleh $\mathrm{F}$ hitung sebesar 39,875 dengan nilai $\mathrm{F}$ tabel 3,07 $(39,875>3,07)$ sehingga Ho ditolak dan Ha diterima. Yang berarti variabel kepercayaan dan keamanan secara simultan berpengaruh terhadap keputusan pembelian barang secara online pada mahasiswa STIE BIMA, dapat diterima.

\section{Kesimpulan dan Saran}

Berdasarkan hasil penelitian yang telah di lakukan, maka peneliti menyimpulkan bahwa kepercayaan berpengaruh secara parsial terhadap keputusan pembelian barang secara onine, keamanan berpengaruh secara parsial terhadap keputusan pembelian barang secara online, serta kepercayaandan keamanan berpengaruh secara simultan terhadap keputusan pembelian barang secara online.Beberapa saran yang penulis ajukan untuk menjadi bahan perbaikan bagi semua orang adalah, Bagi para penjual yang menggunakan media online sebagai tempat berjualan, hendaknya selalu memperhatikan keinginan dari konsumen serta harus selalu menciptakan rasa aman agar kepercayaan dari konsumen meningkat dan tidak akan ragu dalam berbelanja online dan bagi peneliti selanjutnya diharapkan mampu mengembangkan variabel penelitian baru, mengingat pengaruh variabel lain tidak diteliti dalam penelitian ini. Keterbatasan yang di alami peneliti selama melakukan penelitan ini adalah 


\section{Daftar Pustaka}

Alif, G. 2013. Komunikasi Interpersonal Dan Fasilits Kesehatan: Pengaruhnya Terhadap Kepercayaan, Loyalitas Dan Wom Rumah Sakit. (Online). Vol 1, No 3; Oktober 2013. ISNN: 2302-4119. Diakses 13 desember 2019.

Anandita,Florentinus Biger .A, S.Dwi Saputra. 2015, “Analisis Pengaruh Kepercayaan, Keamanan, Kualitas Pelayanan, Dan Persepsi Akan Risiko Terhadap Keputusan Pembelian Melalui Situs Jejaring Sosial", Jurnal Ekonomi dan Kewirausahaan Vol. 15 No $2: 203-210$.

Azwar,S. 2016. Metode Penelitian (Edisi 1) .Yogyakarta: Pustaka Pelajar.

Iskandar, D. 2019. Analisis Pengaruh Kepercayaan, Keamanan, Dan Kualitas Pelayanan Terhadap Keputusan Pembelian Pada Online Shop Lazada: 28-137. Medan, 5 Oktober 2019. Fakultas Ekonomi Dan Bisnis Universitas Muhammadiyah Sumatra Utara.

Mahkota, Andy.P, ET AL. 2014, "Pengaruh Kepercayaan Dan Kenyamanan Terhadap Keputusan Pembelian Online (Studi Pada Pelanggan Website Ride Inc) “, Jurnal Administrasi Bisnis (JAB) | Vol. 8 No. 2.

Sugiyono. (2016). Metode Penelitian Kuantitatif, Kualitatif dan RED. Bandung: PT Alfabet.

Sukma, Abdurahman.A. 2012." Analisis Faktor-Faktor Yang Mempengaruhi Keputusan Pembelian Melalui Social Networking Websites". Jurnal Ekonomi Manajemen,hlm. 300

Sumarwan, U. (2011). Perilaku Konsumen: Teori dan Penerapannya dalam Pemasaran. Bogor: Ghalia Indonesia.

Tugiso, I.ET AL. 2016,"Pengaruh Relationship Marketing, Keamanan, Kepercayaan Dan Kualitas Pelayanan Terhadap Keputusan Pembelian Online Shop Dan Loyalitas Konsumen Sebagai Variabel Intervening" , Journal Of Management, Volume 2 No. 2 maret

Yunita, Nahla.R, dkk. 2019, "Pengaruh Persepsi Risiko, Kepercayaan, Dan Keamanan Terhadap Keputusan Pembelian Online Di Buka Lapak, Jurnal Ekonomi, Manajemen \& Akuntansi, Vol. 3 No. 1 hal $90-105$ 